\title{
Reaction of a Diverse Collection of Barley Lines to Fusarium Head Blight
}

\author{
B. D. McCallum, A. Tekauz, and J. Gilbert, Cereal Research Centre, Agriculture and Agri-Food Canada, Winnipeg, \\ Manitoba, R3T 2M9, Canada
}

\begin{abstract}
McCallum, B. D., Tekauz, A., and Gilbert, J. 2004. Reaction of a diverse collection of barley lines to Fusarium head blight. Plant Dis. 88:167-174.

Fusarium head blight (FHB) is currently the primary disease of concern in barley in Canada and sources of FHB resistance need to be identified. A diverse collection of 77 two-rowed and 81 six-rowed barley lines was screened for resistance to FHB in inoculated, irrigated nurseries from 1995 to 1998. Barley spikes were spray inoculated with conidia of Fusarium graminearum and visual symptoms of FHB were scored to determine an FHB index. Deoxynivalenol (DON) content was determined from harvested seed samples during 1997 and 1998. Although there was variation in the average FHB index and DON content among the different years of testing, the rankings of the lines generally were correlated among the years of testing and the two measures of FHB. Based on the FHB index from 1995 and 1996, a subset of 18 lines with low FHB and 12 lines with high FHB were compared with 20 FHB resistance sources and 7 Canadian lines or cultivars during 1997 and 1998 in both inoculated and noninoculated nurseries. Lines Nepolegajuscij, Krasnojarskij, Nordic, Murakaki-mochi, Golozernyj 1, Maris Mink, Symko, Ussurijskij 8, Suvenir, and Canadian cultivars AC Sterling and Morrison were similar to the best resistance sources (Zhedar1, Seijo II, and Chevron) and had consistently low DON content.
\end{abstract}

Additional keywords: Hordeum vulgare, Gibberella zeae, scab

Fusarium head blight (FHB) rapidly has become the most serious disease in barley (Hordeum vulgare L.) in the eastern prairie region of western Canada (16). FHB on barley was moderate to severe in Manitoba in 1993, 1994, and from 1996 to 1998 (16) and also was more prevalent than in previous years in the southeastern portion of Saskatchewan in $2000(1,14)$. The main causal organism, Fusarium graminearum Schwabe (teleomorph Gibberella zeae (Schwein.) Petch), produces the mycotoxin deoxynivalenol (DON) during infection. Yield losses attributed to FHB infection on barley in Manitoba were estimated at 3.7\% in 1997 (4), $6.3 \%$ in 1998 (5), 3.3\% in 1999 (3), $5.5 \%$ in 2000 (14), and $2.0 \%$ in 2001 (15). Losses in grain quality in barley, due particularly to the accumulation of DON may be more important than the associated yield losses. DON is toxic to animals and humans; therefore, serious FHB infestation makes barley unsuitable for malting, human food, and animal feed (16). Fungicides such as tebuconazole (Folicur) and propiconizole

Corresponding author: B. D. McCallum

E-mail: bmccallum@agr.gc.ca

Agriculture and Agri-Food Canada, Cereal Research Centre contribution \#1846.

Accepted for publication 5 September 2003.

Publication no. D-2003-1124-03R

(C) 2004 Minister of Public Works and Government Services Canada
(Tilt) have some effect on reducing FHB and DON content in cereal grains, but resistant cultivars represent the most economical and environmentally acceptable method of disease management (8).

Efforts are underway to develop barley cultivars with improved levels of resistance to FHB to help minimize the destructive effects of the disease. If barley lines with superior FHB resistance were identified, they could be used as parents to breed barley cultivars with improved FHB resistance, but genetic resistance to $\mathrm{FHB}$ in barley is not well characterized. Takeda and Heta (13) screened approximately 5,000 barley lines from diverse origins, both two- and six-rowed, for FHB resistance under controlled conditions and in field screening nurseries. From three successive rounds of screening, they identified 23 elite two-rowed lines with superior FHB resistance. Other reported sources of resistance were the cultivars Chevron (9), Shyri, Gobernadora, Atahualpa, Zhedar 1, and Zhedar 2 (2).

The objective of this study was to screen a diverse collection of barley germ plasm for resistance to FHB. The most promising lines from an initial screen then were compared for resistance with lines reported previously to have some level of resistance to FHB.

\section{MATERIALS AND METHODS}

A diverse collection of 158 barley lines, 77 two-rowed and 81 six-rowed, was chosen from the collection of the Plant Genetic Resources (PGR) unit of Agriculture and Agri-Food Canada. Lines were chosen from geographically different sources of origin to sample a wide variety of barley germ plasm. The lines were screened for resistance to FHB in a nursery inoculated with $F$. graminearum in 1995,1996 , and 1998 at Glenlea, MB and in 1997 at Morden, MB. Single 1.5-m rows were planted every year for each entry. Barley spikes were spray inoculated at heading and again at 7 days after heading. For each inoculation, every row was sprayed with approximately $100 \mathrm{ml}$ of a suspension containing $5.0 \times 10^{4} \mathrm{~F}$. graminearum macroconidia per milliliter of $\mathrm{H}_{2} \mathrm{O}$. To prepare this suspension, four isolates of $F$. graminearum, previously isolated from FHB-infected barley spikes in Manitoba, were separately grown on petri plates containing potato dextrose agar. Colonized agar from one petri plate per isolate was cut into small pieces (approximately 2 by 2 $\mathrm{cm})$ and transferred to a flask containing 1 liter of liquid medium (15.0 $\mathrm{g}$ of carboxymethyl cellulose, $1 \mathrm{~g}$ of $\mathrm{NH}_{4} \mathrm{NO}_{3}, 1 \mathrm{~g}$ of $\mathrm{KH}_{2} \mathrm{PO}_{4}, 0.5 \mathrm{~g}$ of $\mathrm{MgSO}_{4} \cdot 7 \mathrm{H}_{2} \mathrm{O}, 1 \mathrm{~g}$ of yeast extract, and 1 liter of $\mathrm{H}_{2} \mathrm{O}$ ). The liquid cultures were grown with continuous aeration at room temperature for approximately 5 days, filtered through cheese cloth to remove the pieces of agar, and then diluted to a concentration of $5.0 \times 10^{4}$ macroconidia/ml with $\mathrm{H}_{2} \mathrm{O}$. One drop of the surfactant Tween 20 was added per liter of macroconidial suspension. Mist irrigation was provided after each inoculation and at regular intervals afterward.

Fourteen days after the final inoculation, all the spikes were harvested from a $60-\mathrm{cm}$ section in the middle of each row and frozen at $-20^{\circ} \mathrm{C}$. The spikes subsequently were thawed and the immature spikes from late maturing tillers, which could have escaped inoculation, were discarded. The FHB index (incidence $x$ average severity), was calculated for each line on approximately 30 spikes to determine the level of FHB infection based on visual symptoms. Incidence (infected spikes/total spikes) was determined by counting the number of spikes with discolored spikelets that are indicative of FHB from approximately 30 mature spikes. Discolored spikelets appeared typically as tan, brown, or sometimes dark brown or black compared with the healthy green spikelets. Average severity was determined by dividing the mean number of infected spikelets by the mean number of total spikelets. Discolored spikelets per spike were counted from all infected spikes and the number averaged to 
Table 1. Fusarium head blight (FHB) index and deoxynivalenol (DON) concentration for 158 barley lines inoculated with Fusarium graminearum in irrigated nurseries in 1995, 1996, 1997, and 1998 a

\begin{tabular}{|c|c|c|c|c|c|c|c|c|c|c|}
\hline \multirow[b]{2}{*}{ Cultivar } & \multirow[b]{2}{*}{ Designation } & \multirow[b]{2}{*}{ Row } & \multicolumn{4}{|c|}{ FHB index (\%) } & \multirow[b]{2}{*}{ Mean $^{\text {b }}$} & \multirow[b]{2}{*}{ Transformed mean ${ }^{c}$} & \multicolumn{2}{|c|}{ DON (ppm) } \\
\hline & & & 1995 & 1996 & 1997 & 1998 & & & 1997 & 1998 \\
\hline Nepolegajuscij & PGR0001240 & 2 & 1.2 & 10.3 & 10.2 & 5.7 & 6.1 & 2.5 & 2.6 & 0.2 \\
\hline Murasaki-mochi & PGR0016961 & 6 & 2.3 & 8.4 & 9.4 & 8.4 & 6.7 & 2.6 & 0.1 & 5.2 \\
\hline Nordic & PGR0012721 & 6 & 6.7 & 10.4 & 14.6 & 2.0 & 7.6 & 2.8 & 3.2 & 1.3 \\
\hline Symko & PGR0017142 & 2 & 0.4 & 9.3 & 32.9 & 2.9 & 7.7 & 2.8 & 3.7 & 0.4 \\
\hline Krasnojarskij 1 & PGR0001594 & 2 & 8.0 & 8.4 & 10.7 & 5.5 & 8.0 & 2.8 & 4.4 & 1.3 \\
\hline Dziugiaj & PGR0001590 & 2 & 1.4 & 18.2 & 8.7 & 9.1 & 8.1 & 2.9 & 3.9 & 0.5 \\
\hline Golozernyj 1 & PGR0008202 & 2 & 3.4 & 10.7 & 19.3 & 5.0 & 8.6 & 2.9 & 0.5 & 0.5 \\
\hline PI25744 Franconian & CIho000679 & 2 & 4.0 & 13.9 & 10.9 & 8.7 & 9.0 & 3.0 & 1.6 & 0.3 \\
\hline PI28596 Black Algerian & CIho000708 & 6 & 8.9 & 6.6 & 12.6 & 9.2 & 9.2 & 3.0 & 8.6 & 0.9 \\
\hline Nosovskij 6 & PGR0001593 & 2 & 2.3 & 15.1 & 16.2 & 7.8 & 9.3 & 3.1 & 3.5 & 0.3 \\
\hline Duncan & PGR0002045 & 2 & 1.0 & 16.5 & 25.4 & 4.6 & 9.4 & 3.1 & 2.6 & $\ldots$ \\
\hline Hazen & PGR0026752 & 6 & 1.4 & 1.9 & 49.8 & 7.5 & 9.5 & 3.1 & 5.2 & 1.3 \\
\hline Tristan & PGR0002046 & 2 & 0.6 & 15.5 & 32.8 & 3.7 & 9.6 & 3.1 & 1.1 & 1.8 \\
\hline Suvenir & PGR0001243 & 2 & 4.8 & 7.6 & 10.9 & 19.3 & 10.0 & 3.2 & 2.3 & $\ldots$ \\
\hline Maris Mink & PGR0001804 & 2 & 4.5 & 12.2 & 17.1 & 8.5 & 10.0 & 3.2 & 2.8 & $\ldots$ \\
\hline Helong 2r & PGR0026739 & 6 & 3.6 & 16.0 & 26.4 & 3.1 & 10.2 & 3.2 & 2.6 & 1.6 \\
\hline Tellus & PGR0012731 & 2 & 5.7 & 19.5 & 15.2 & 4.8 & 10.4 & 3.2 & 6.6 & $\ldots$ \\
\hline Ussurijskij 8 & PGR0000009 & 2 & 0.2 & 11.2 & 31.6 & 12.9 & 10.6 & 3.3 & 1.1 & 0.3 \\
\hline Andre & PGR0026736 & 2 & 8.9 & 12.7 & 17.8 & 5.3 & 10.7 & 3.3 & 0.3 & 2.4 \\
\hline Summit & PGR0005746 & 2 & 2.6 & 14.8 & 26.8 & 6.9 & 11.0 & 3.3 & 4.3 & 4.1 \\
\hline Clho 1340 Goldthorpe & CIho001340 & 2 & 4.3 & 17.2 & 23.2 & 5.3 & 11.1 & 3.3 & 9.0 & 2.0 \\
\hline CIho 1609 O.A.C. 38 & CIho001609 & 2 & 3.0 & 19.1 & 33.1 & 2.4 & 11.2 & 3.4 & 2.9 & 0.9 \\
\hline Stepovyj & PGR0001001 & 2 & 1.0 & 18.6 & 22.6 & 11.2 & 11.2 & 3.4 & 3.2 & 0.4 \\
\hline ZAO-SU 3 & PGR0026740 & 2 & 7.0 & 5.7 & 24.9 & 12.2 & 11.4 & 3.4 & 2.3 & 7.5 \\
\hline Freja & PGR0002804 & 2 & 2.8 & 27.9 & 10.2 & 11.5 & 11.5 & 3.4 & 3.1 & 0.3 \\
\hline Timiriazevskij 85 & PGR0013306 & 6 & 11.2 & 20.2 & 3.9 & 17.4 & 12.2 & 3.5 & 2.8 & 5.3 \\
\hline Odesskij 36 & PGR0013298 & 2 & 6.9 & 20.8 & 18.6 & 6.6 & 12.4 & 3.5 & 10.1 & 0.7 \\
\hline Clho 1243 Abyssinian & CIho001243 & 6 & 2.1 & 32.6 & 23.5 & 4.4 & 12.4 & 3.5 & 7.2 & 0.9 \\
\hline CIho 1554 Hanna & CIho001554 & 2 & 7.7 & 4.2 & 54.4 & 4.0 & 12.6 & 3.5 & 5.7 & 0.6 \\
\hline CIho 657 Chile Brewing & CIho000657 & 6 & 7.1 & 17.1 & 32.2 & 3.4 & 12.8 & 3.6 & 0.7 & $\ldots$ \\
\hline Mensury Ottawa 60 & PGR0004995 & 6 & 16.2 & 22.8 & 12.2 & 4.3 & 12.9 & 3.6 & 5.1 & 0.7 \\
\hline Mari & PGR0001755 & 2 & 5.5 & 13.2 & 10.5 & 26.7 & 12.9 & 3.6 & 7.9 & 6.9 \\
\hline PI19894 Wakamatsu & CIho000579 & 6 & 4.5 & 11.6 & 27.5 & 13.4 & 13.0 & 3.6 & 0.2 & 5.9 \\
\hline CIho 1365 Bolivia & CIho001365 & 6 & 5.8 & 17.4 & 25.6 & 7.8 & 13.0 & 3.6 & 6.4 & 1.6 \\
\hline Moskovskij 121 & PGR0013301 & 2 & 8.8 & 20.1 & 26.8 & 3.3 & 13.0 & 3.6 & 2.2 & 0.6 \\
\hline CIho 1970 Gartons 66 & CIho001970 & 6 & 4.6 & 9.3 & 41.3 & 8.1 & 13.1 & 3.6 & 10.2 & 0.8 \\
\hline PI26179 Barbary & CIho000695 & 6 & 6.4 & 15.3 & 25.1 & 9.2 & 13.1 & 3.6 & 0.2 & 1.7 \\
\hline Manker & PGR0013125 & 6 & 3.7 & 10.7 & 18.8 & 25.4 & 13.3 & 3.6 & 6.5 & 2.7 \\
\hline Gazelle & PGR0019893 & 2 & 4.8 & 15.8 & 44.6 & 3.0 & 13.3 & 3.6 & 4.0 & 0.2 \\
\hline Doneckij 4 & PGR0013299 & 2 & 5.1 & 16.4 & 35.2 & 5.8 & 13.4 & 3.7 & 6.4 & 0.7 \\
\hline CIho 1137 Oderbrucker & CIho001137 & 6 & 8.4 & 20.6 & 21.0 & 7.0 & 13.4 & 3.7 & 10.8 & 2.3 \\
\hline Gryf & PGR0017846 & 2 & 2.9 & 14.9 & 47.6 & 5.2 & 13.6 & 3.7 & 5.5 & 0.3 \\
\hline H. dis. nigrinudum No. 1 & P3GR0016858 & 2 & 9.6 & 16.8 & 18.2 & 10.8 & 13.6 & 3.7 & 12.4 & 4.6 \\
\hline Arvo & PGR0002059 & 2 & 7.6 & 23.5 & 24.6 & 5.1 & 13.7 & 3.7 & 1.7 & \\
\hline Early Russian/CI13839 & PGR0002066 & 6 & 14.5 & 11.2 & 21.3 & 9.7 & 13.8 & 3.7 & 6.4 & 3.6 \\
\hline CIho 1131 Peruvian & CIho001131 & 6 & 3.7 & 20.2 & 28.7 & 10.1 & 14.0 & 3.7 & 14.3 & 2.5 \\
\hline Taplani & PGR0017879 & 2 & 0.6 & 25.4 & 54.8 & 3.2 & 14.1 & 3.8 & 2.3 & 11.3 \\
\hline Juznyj & PGR0001002 & 2 & 2.6 & 22.5 & 17.5 & 20.7 & 14.2 & 3.8 & 6.1 & 2.0 \\
\hline Mazurka & PGR0010077 & 2 & 1.1 & 42.2 & 31.5 & 4.0 & 14.4 & 3.8 & 5.1 & $\ldots$ \\
\hline LB.IRAN-3 & PGR0022309 & 6 & 3.5 & 16.5 & 32.8 & 12.4 & 14.4 & 3.8 & 5.0 & $\ldots$ \\
\hline Vinnickij 7 & PGR0012988 & 2 & 2.8 & 20.0 & 41.4 & 6.8 & 14.4 & 3.8 & 1.9 & $\ldots$ \\
\hline Karat & PGR0016076 & 2 & 8.8 & 17.3 & 19.3 & 13.6 & 14.5 & 3.8 & 1.7 & $\ldots$ \\
\hline Zhouma 12 & PGR0026741 & 2 & 6.6 & 13.8 & 26.3 & 14.4 & 14.5 & 3.8 & 7.8 & 7.3 \\
\hline Moscovskij 121 & PGR0001591 & 2 & 3.4 & 13.9 & 26.1 & 20.8 & 14.5 & 3.8 & 0.9 & 3.4 \\
\hline Morex & PGR0013126 & 6 & 28.0 & 19.3 & 4.8 & 11.9 & 14.7 & 3.8 & 6.7 & 2.9 \\
\hline Krasnodarskij 35 & PGR0001242 & 2 & 3.8 & 14.6 & 32.1 & 15.2 & 14.7 & 3.8 & 5.4 & 3.4 \\
\hline Wing & PGR0002000 & 2 & 2.6 & 12.9 & 16.7 & 39.5 & 15.2 & 3.9 & 1.2 & 0.1 \\
\hline CIho 933 Bohemian & CIho000933 & 2 & 2.4 & 26.9 & 42.8 & 5.8 & 15.4 & 3.9 & 4.0 & 1.0 \\
\hline Clho1392 Sealand Prentice & CIho001392 & 2 & 13.9 & 17.8 & 27.4 & 6.5 & 15.5 & 3.9 & 4.2 & $\ldots$ \\
\hline Midas & PGR0002014 & 2 & 6.8 & 23.0 & 37.9 & 5.5 & 15.8 & 4.0 & 0.6 & $\ldots$ \\
\hline Karri & PGR0008758 & 2 & 2.0 & 40.0 & 25.2 & 9.9 & 15.8 & 4.0 & 1.4 & $\ldots$ \\
\hline Akka W6039 & PGR0002138 & 2 & 2.9 & 10.0 & 39.4 & 22.7 & 15.8 & 4.0 & 3.4 & 5.2 \\
\hline LB.IRAN-1 & PGR0022297 & 6 & 1.9 & 22.4 & 39.6 & 12.8 & 16.0 & 4.0 & 0.9 & 0.2 \\
\hline PI24159 Szechwan & CIho000664 & 6 & 7.7 & 18.3 & 30.4 & 12.0 & 16.1 & 4.0 & 12.4 & 2.3 \\
\hline Manchuria & PGR0004980 & 6 & 16.6 & 22.1 & 31.6 & 3.1 & 16.3 & 4.0 & 6.4 & 13.2 \\
\hline Sofia & PGR0015534 & 6 & 0.6 & 46.7 & 40.1 & 5.0 & 16.4 & 4.0 & 5.8 & 0.4 \\
\hline CIho 392 Moldavia & CIho000392 & 6 & 6.7 & 29.1 & 30.8 & 7.4 & 16.5 & 4.1 & 1.5 & 2.4 \\
\hline \multirow[t]{2}{*}{ La Sa-bai } & PGR0016595 & 6 & 5.7 & 25.4 & 20.3 & 18.8 & 16.5 & 4.1 & 10.7 & 7.4 \\
\hline & & & & & & & & (cont) & ed on & xt page \\
\hline
\end{tabular}

a ... Indicates missing data or not applicable.

${ }^{\mathrm{b}}$ Means were obtained by squaring the transformed mean.

${ }^{\mathrm{c}}$ Mean of the FHB index transformed by square root. The least significant difference $(P \leq 0.05)$ between the transformed mean for any two lines is 1.8 . 
Table 1. (continued from preceding page)

\begin{tabular}{|c|c|c|c|c|c|c|c|c|c|c|}
\hline \multirow[b]{2}{*}{ Cultivar } & \multirow[b]{2}{*}{ Designation } & \multirow[b]{2}{*}{ Row } & \multicolumn{4}{|c|}{ FHB index (\%) } & \multirow[b]{2}{*}{ Mean $^{b}$} & \multirow[b]{2}{*}{ Transformed mean ${ }^{\mathrm{c}}$} & \multicolumn{2}{|c|}{ DON (ppm) } \\
\hline & & & 1995 & 1996 & 1997 & 1998 & & & 1997 & 1998 \\
\hline Mx 37 Keystone & PGR0007162 & 6 & 3.1 & 26.2 & 42.4 & 8.5 & 16.6 & 4.1 & 6.1 & 0.5 \\
\hline Svalof 50-109 & PGR0002818 & 2 & 2.8 & 28.6 & 21.6 & 22.2 & 16.8 & 4.1 & 4.9 & 0.5 \\
\hline CIho 935 Peruvian & CIho000935 & 6 & 8.2 & 27.2 & 30.4 & 8.0 & 16.9 & 4.1 & 4.6 & 3.1 \\
\hline Belogorskij & PGR0013310 & 6 & 3.6 & 32.8 & 40.9 & 6.3 & 17.1 & 4.1 & 4.9 & 0.7 \\
\hline PI22494 Manchuria & CIho000643 & 6 & 4.8 & 25.5 & 47.0 & 6.2 & 17.2 & 4.1 & 5.6 & 0.3 \\
\hline CIho 1892 Champion of Vermont & CIho001892 & 2 & 2.5 & 30.3 & 59.6 & 3.2 & 17.2 & 4.1 & 6.2 & 0.4 \\
\hline Zephyr & PGR0012740 & 2 & 5.4 & 48.2 & 23.3 & 7.1 & 17.6 & 4.2 & 3.8 & $\ldots$ \\
\hline Celinnij 5 & PGR0001776 & 2 & 4.7 & 26.1 & 19.5 & 25.7 & 17.6 & 4.2 & 1.9 & 0.5 \\
\hline Desnianskij 8 & PGR0008203 & 2 & 9.1 & 27.5 & 20.8 & 16.2 & 17.7 & 4.2 & 2.7 & \\
\hline Zaoshu 3 & PGR0017043 & 2 & 8.0 & 27.1 & 18.7 & 20.5 & 17.8 & 4.2 & 6.3 & 7.5 \\
\hline Hassan & PGR0001975 & 2 & 4.3 & 12.7 & 31.6 & 32.1 & 17.9 & 4.2 & 3.0 & 0.3 \\
\hline CIho 1686 Swedish star & CIho001686 & 6 & 8.6 & 18.5 & 34.4 & 14.8 & 17.9 & 4.2 & 1.4 & 1.0 \\
\hline Bacchus & PGR0013327 & 2 & 2.4 & 23.8 & 41.1 & 17.6 & 18.1 & 4.3 & 5.1 & 0.2 \\
\hline Atlanta & PGR0005017 & 2 & 3.0 & 36.9 & 43.9 & 7.5 & 18.4 & 4.3 & 2.5 & 0.7 \\
\hline Rhodes & PGR0022313 & 6 & 3.9 & 38.9 & 37.6 & 8.3 & 18.5 & 4.3 & 12.1 & 5.7 \\
\hline Sever 1 & PGR0008204 & 2 & 3.5 & 29.2 & 27.3 & 22.6 & 18.6 & 4.3 & 2.1 & 0.5 \\
\hline Odesskij 46 & PGR0008205 & 6 & 2.0 & 43.8 & 31.3 & 13.8 & 18.8 & 4.3 & 6.0 & 0.5 \\
\hline PI48133 Coast & CIho001430 & 6 & 4.4 & 33.2 & 30.3 & 16.2 & 18.9 & 4.3 & 6.9 & 8.4 \\
\hline PI25671 Ireland & CIho001603 & 6 & 12.0 & 24.6 & 30.8 & 12.5 & 19.2 & 4.4 & 10.9 & 0.2 \\
\hline Aizao 3 & PGR0026738 & 2 & 11.2 & 11.3 & 18.9 & 41.8 & 19.2 & 4.4 & 16.6 & 17.1 \\
\hline Glenn & PGR0012235 & 6 & 25.5 & 15.4 & 22.9 & 15.9 & 19.7 & 4.4 & 6.4 & 3.7 \\
\hline Trompillo & PGR0021256 & 2 & 6.3 & 27.9 & 45.2 & 10.5 & 19.7 & 4.4 & 1.7 & 8.4 \\
\hline Helena & PGR0018007 & 2 & 3.8 & 28.8 & 62.0 & 6.7 & 19.8 & 4.4 & 10.2 & 3.9 \\
\hline PI48195 Mecknes Maroc & CIho001379 & 6 & 6.6 & 20.3 & 43.1 & 17.6 & 19.9 & 4.5 & 5.5 & 2.8 \\
\hline Georgie & PGR0013380 & 2 & 3.9 & 35.7 & 23.4 & 25.9 & 20.0 & 4.5 & 5.9 & 0.6 \\
\hline Bowers & PGR0012231 & 6 & 24.8 & 24.8 & 38.2 & 3.2 & 20.1 & 4.5 & 17.2 & 1.5 \\
\hline Jupiter & PGR0013330 & 2 & 8.1 & 25.5 & 43.4 & 13.6 & 20.6 & 4.5 & 2.0 & 2.3 \\
\hline Stavropol & PGR0004963 & 6 & 24.0 & 25.4 & 37.0 & 4.7 & 20.7 & 4.5 & 6.3 & 1.2 \\
\hline Kym & PGR0016073 & 2 & 7.9 & 24.4 & 28.9 & 27.5 & 21.1 & 4.6 & 2.4 & 0.3 \\
\hline PI38887 Barbican & CIho001265 & 6 & 2.1 & 43.4 & 47.2 & 12.5 & 21.3 & 4.6 & 10.5 & 1.1 \\
\hline Liang lan ging ke & PGR0000308 & 6 & 12.4 & 14.2 & 33.6 & 29.2 & 21.4 & 4.6 & 3.2 & 0.6 \\
\hline CIho 1118 Featherston & CIho001118 & 6 & 6.2 & 26.3 & 62.2 & 9.3 & 21.5 & 4.6 & 15.9 & 0.3 \\
\hline Omskij 13709 & PGR0013300 & 2 & 7.2 & 53.5 & 39.0 & 5.4 & 21.5 & 4.6 & 8.3 & 0.2 \\
\hline CIho 1654 Chili & CIho001654 & 6 & 7.9 & 15.2 & 47.4 & 27.0 & 22.1 & 4.7 & 10.6 & 0.8 \\
\hline Hankkija 34003 & PGR0002047 & 2 & 10.3 & 26.5 & 20.8 & 35.4 & 22.2 & 4.7 & 1.7 & 8.1 \\
\hline PI31765 Haua & CIho000734 & 6 & 6.8 & 26.3 & 52.2 & 16.3 & 22.6 & 4.7 & 11.9 & 6.7 \\
\hline CIho 1370 Spain & CIho001370 & 6 & 10.6 & 33.3 & 32.0 & 19.8 & 22.9 & 4.8 & 10.4 & 1.5 \\
\hline CIho 1397 Mansury & CIho001397 & 6 & 4.8 & 26.1 & 81.0 & 8.4 & 23.0 & 4.8 & 9.6 & 0.4 \\
\hline Zao Shu no. 3 (Early) & PGR0000304 & 2 & 10.8 & 30.6 & 21.3 & 34.8 & 23.4 & 4.8 & 7.4 & 5.2 \\
\hline CIho 2203 Boehmes Beardless & CIho002203 & 6 & 6.7 & 25.3 & 47.5 & $\ldots$ & 23.4 & 4.8 & 14.6 & $\ldots$ \\
\hline Candice & PGR0016072 & 2 & 7.2 & 50.4 & 30.9 & 17.1 & 23.7 & 4.9 & 6.0 & 1.1 \\
\hline Otro & PGR0001959 & 6 & 3.5 & 26.9 & 40.4 & 36.9 & 23.7 & 4.9 & 14.8 & 8.4 \\
\hline Triumph & PGR0013387 & 2 & 3.9 & 25.0 & 41.6 & 37.9 & 24.0 & 4.9 & 4.3 & 1.3 \\
\hline CIho 1871 Turkish & CIho001871 & 2 & 8.2 & 25.5 & 70.7 & 11.8 & 24.4 & 4.9 & 8.9 & 0.3 \\
\hline Katsu & PGR0004955 & 6 & 16.4 & 15.0 & 47.1 & 25.3 & 24.5 & 5.0 & 7.2 & 6.2 \\
\hline 45 & PGR0000600 & 2 & 6.7 & 9.6 & 43.4 & 57.0 & 24.6 & 5.0 & 11.0 & 14.0 \\
\hline Hankkija 673 & PGR0001960 & 6 & 5.9 & 35.2 & 39.2 & 27.1 & 24.6 & 5.0 & 13.1 & 6.6 \\
\hline PI48135 Chilean C & CIho001432 & 6 & 5.9 & 19.5 & 82.4 & 16.0 & 24.8 & 5.0 & 16.8 & 6.9 \\
\hline PI42100 Cape & CIho001268 & 6 & 10.0 & 26.8 & 43.6 & 25.1 & 24.9 & 5.0 & 4.3 & 6.6 \\
\hline Hellas & PGR0012712 & 2 & 7.3 & 18.6 & 54.6 & 31.5 & 25.0 & 5.0 & 6.1 & \\
\hline Bavaria & PGR0002136 & 2 & 10.9 & 15.6 & 48.6 & 34.1 & 25.2 & 5.0 & 1.6 & 0.8 \\
\hline PI29003 Turkestan & CIho000711 & 6 & 34.9 & 12.9 & 55.0 & 10.9 & 25.5 & 5.1 & 0.7 & 0.3 \\
\hline Jotun & PGR0002058 & 6 & 3.8 & 29.9 & 57.4 & 28.0 & 25.7 & 5.1 & 12.1 & 4.1 \\
\hline Zita & PGR0015585 & 2 & 6.2 & 56.0 & 36.4 & 18.7 & 25.8 & 5.1 & 4.4 & 0.4 \\
\hline CIho 1351 Andrew & CIho001351 & 6 & 8.9 & 25.1 & 63.0 & 19.8 & 26.0 & 5.1 & 15.9 & 5.0 \\
\hline Betzes ms 16 & PGR0002823 & 2 & 10.6 & 41.0 & 30.2 & 27.8 & 26.1 & 5.1 & 1.1 & 0.5 \\
\hline CIho 927 Odessa & CIho000927 & 6 & 8.5 & 24.3 & 73.7 & 18.0 & 26.7 & 5.2 & 13.4 & 1.6 \\
\hline Xarkovscij 60 & PGR0004102 & 6 & 39.0 & & 34.8 & 11.5 & 26.8 & 5.2 & 1.8 & 0.5 \\
\hline Koru & PGR0013381 & 2 & 9.5 & 57.2 & 37.9 & 15.6 & 26.9 & 5.2 & 2.5 & 13.6 \\
\hline Varunda & PGR0012734 & 2 & 4.8 & 56.4 & 29.2 & 32.1 & 27.0 & 5.2 & 3.2 & 24.2 \\
\hline Paavo & PGR0002107 & 6 & 5.8 & 60.7 & 23.3 & 36.7 & 27.8 & 5.3 & 4.9 & 1.1 \\
\hline Sultan & PGR0002131 & 2 & 11.9 & 35.2 & 54.9 & 18.6 & 27.8 & 5.3 & 3.4 & 0.4 \\
\hline Luc & PGR0001597 & 2 & 12.8 & 33.6 & 28.4 & 44.8 & 28.6 & 5.3 & 2.2 & $\ldots$ \\
\hline Bai lang Sanging ke & PGR0000316 & 6 & 14.3 & 8.9 & 44.7 & 63.5 & 28.7 & 5.4 & 1.3 & 1.2 \\
\hline PI38321 Pasha & CIho000984 & 6 & $\ldots$ & 18.7 & 48.1 & 23.6 & 28.9 & 5.4 & 10.3 & 4.4 \\
\hline 140 Pin $X i$ & PGR0000311 & 6 & 9.2 & 27.0 & 27.7 & 64.8 & 29.0 & 5.4 & 5.7 & 1.4 \\
\hline Celinnyj 5 & PGR0012989 & 6 & 5.8 & 51.9 & 60.1 & 22.8 & 30.6 & 5.5 & 12.0 & 3.2 \\
\hline CIho 1357 Minorca & CIho001357 & 6 & 22.7 & 29.0 & 45.0 & 29.3 & 31.0 & 5.6 & 15.8 & 4.2 \\
\hline Hankkijan Pokko & PGR0016366 & 6 & 10.4 & 39.1 & 47.1 & 36.0 & 31.2 & 5.6 & 6.9 & 1.6 \\
\hline PI48641 Fidel & CIho001445 & 2 & 12.7 & 53.2 & 61.4 & 13.9 & 31.4 & 5.6 & 58.7 & 0.1 \\
\hline Du Li-huang & PGR0016598 & 6 & 9.0 & 52.3 & 41.3 & 33.9 & 31.6 & 5.6 & 4.7 & 1.1 \\
\hline & & & & & & & & $(\mathrm{co}$ & led on & xt page \\
\hline
\end{tabular}


Table 1. (continued from preceding page)

\begin{tabular}{|c|c|c|c|c|c|c|c|c|c|c|}
\hline \multirow[b]{2}{*}{ Cultivar } & \multirow[b]{2}{*}{ Designation } & \multirow[b]{2}{*}{ Row } & \multicolumn{4}{|c|}{ FHB index (\%) } & \multirow[b]{2}{*}{ Mean $^{b}$} & \multirow[b]{2}{*}{ Transformed mean ${ }^{c}$} & \multicolumn{2}{|c|}{ DON (ppm) } \\
\hline & & & 1995 & 1996 & 1997 & 1998 & & & 1997 & 1998 \\
\hline Brachytic & PGR0002083 & 6 & 8.3 & 39.6 & 42.3 & 46.9 & 31.7 & 5.6 & 9.2 & 13.3 \\
\hline Rabat & PGR0005019 & 6 & 12.2 & 48.7 & 53.0 & 23.5 & 31.9 & 5.6 & 6.8 & 14.0 \\
\hline Minskij & PGR0001777 & 2 & 10.7 & 18.6 & 60.6 & 52.4 & 31.9 & 5.7 & 2.9 & $\ldots$ \\
\hline CIho 1556 Minsturdi & CIho001556 & 6 & 29.9 & 21.5 & 69.5 & 21.0 & 33.1 & 5.8 & 18.7 & 7.9 \\
\hline CIho 1576 Early Indian & CIho001576 & 6 & 19.7 & 38.4 & 43.3 & 34.0 & 33.2 & 5.8 & 19.4 & 3.5 \\
\hline Dissa & PGR0015533 & 6 & 6.5 & 70.1 & 59.2 & 26.2 & 35.2 & 5.9 & 14.4 & $\ldots$ \\
\hline N33 & PGR0000800 & 6 & 3.7 & 62.2 & 32.4 & 68.8 & 35.4 & 5.9 & 22.2 & 14.1 \\
\hline Suvi & PGR0008368 & 6 & 25.0 & 53.8 & 16.7 & 61.4 & 36.8 & 6.1 & 12.1 & 15.7 \\
\hline Nan fan no. 4 & PGR0000305 & 6 & 7.1 & 54.0 & 42.0 & 61.4 & 37.0 & 6.1 & 5.6 & 3.5 \\
\hline Beecher & PGR0004979 & 6 & 50.5 & 31.4 & 32.7 & 35.4 & 37.1 & 6.1 & 15.0 & 1.4 \\
\hline Pohto & PGR0019986 & 6 & 14.1 & $\ldots$ & 54.0 & 56.0 & 38.4 & 6.2 & 20.7 & 7.3 \\
\hline Hankkijan Potra & PGR0016367 & 6 & 16.3 & 60.3 & 36.3 & 57.4 & 40.3 & 6.4 & 12.6 & 16.1 \\
\hline Pomo & PGR0008366 & 6 & 28.7 & 30.5 & 54.5 & 61.5 & 42.6 & 6.5 & 3.0 & $\ldots$ \\
\hline Etu & PGR0008365 & 6 & 7.9 & 54.9 & 61.1 & 65.1 & 42.6 & 6.5 & 8.9 & 6.9 \\
\hline Hiproly & PGR0002099 & 2 & 17.6 & 53.9 & 47.2 & 62.0 & 43.2 & 6.6 & 25.3 & $\ldots$ \\
\hline Hх690 & PGR0007182 & 6 & 54.5 & 56.7 & 50.9 & 21.2 & 44.4 & 6.7 & 19.6 & 5.0 \\
\hline PI39400 Czech & CIho001023 & 6 & $\ldots$ & 58.2 & 31.8 & 77.9 & 54.2 & 7.4 & 30.0 & 4.7 \\
\hline PI38307 Rasput & CIho000996 & 6 & $\ldots$ & 62.5 & 68.5 & 49.6 & 59.9 & 7.7 & 10.9 & 6.3 \\
\hline Bai liu ling & PGR0000307 & 6 & 53.5 & 55.2 & $\ldots$ & 78.8 & 62.0 & 7.9 & 4.6 & $\ldots$ \\
\hline Mean & $\ldots$ & $\ldots$ & 8.6 & 26.5 & 35.2 & 19.9 & 20.5 & 4.4 & 7.1 & 3.5 \\
\hline
\end{tabular}

determine the mean infected spikelets. The total spikelets per spike also were counted for a subset of 20 spikes, randomly selected from the original sample of 30 mature spikes, and averaged to determine the mean total spikelets for each line.

Based on their FHB index values in 1995 and 1996, a subset of 18 lines with low FHB index values (LFHB) and 12 lines with relatively high FHB index values (HFHB) from the original sample of 158 was selected for comparison with 27 barley accessions (resistance sources [RS]). The RS lines included 20 cultivars previously reported to have some level of FHB resistance $(2,9,13)$ or thought to have resistance, and 7 Canadian cultivars or lines (AC Sterling, AC Stephen, T-186-1, DB 202, DB 192, Morrison, and AB 1592). Many of these Canadian cultivars or lines are related to Symko (one of the LFHB lines). These 57 barley lines (LFHB $+\mathrm{HFHB}+\mathrm{RS}$ ) were grown in single 1.5$\mathrm{m}$ rows and evaluated for FHB reaction in inoculated, irrigated nurseries at Morden, MB during 1997 and at Glenlea, MB during 1998, using the methods described above. These accessions also were evaluated under natural FHB infection conditions without artificial inoculation or irrigation at Carman, MB in 1997 and 1998. The plots were grown and visual FHB was determined as described previously for the inoculated nurseries, except spikes were sampled when symptoms of FHB were evident because no exogenous inoculum was applied.

Samples for DON analysis were obtained from the 1997 and 1998 trials by harvesting the remainder of each row at maturity. Harvested grain (20 g) was subsampled from each line and ground using a UDY Cyclone (UDY Corporation Fort Collins, CO) with a $0.5-\mathrm{mm}$ screen. The ground sample was mixed, and a 1.0-g subsample was dispensed into a $12.5-\mathrm{ml}$ centrifuge tube and analyzed for DON content by enzyme-linked immunosorbent assay (11).

The data were analyzed using SAS program PROC GLM (version 6.12; SAS Institute, Cary NC). The FHB index values were transformed using the square root transformation (index $=\operatorname{sqrt}[$ index]) and the DON values were transformed using a $\log$ transformation $(\mathrm{DON}=\log [0.5+$ DON]) to stabilize the variance. Spearman rank correlation statistics based on FHB index values and DON were determined using PROC CORR.

\section{RESULTS}

The FHB index and DON content for 158 barley lines from the $F$. graminearum inoculated nurseries from 1995 to 1998 are listed in Table 1. For the FHB index, the effects of year, two-rowed versus sixrowed type, and cultivar were all significant $(P \leq 0.05)$. The average FHB index varied from 8.6 in 1995 to 19.9 in 1998 , 26.5 in 1996, and 35.2 in 1997 (Table 1). The nursery is located in an area in which FHB occurs regularly at relatively high levels; therefore, there is a background of natural inoculum and disease pressure that affects the level of FHB within the inoculated nursery plants. The infection level of FHB also is affected by environmental conditions such as humidity, precipitation, and temperature (6). Therefore, the actual inoculum pressure varied from year to year despite efforts to quantify the exogenously supplied inoculum and irrigation.

The 77 two-rowed cultivars had significantly lower average FHB index values than the 81 six-rowed cultivars. The average FHB index also was lower for tworowed than for six-rowed cultivars in each of the four years of testing (5.7 versus 11.4 in $1995,23.8$ versus 29.0 in $1996,31.2$ versus 38.9 in 1997, and 16.4 versus 23.3 in 1998). The lines are ranked in Table 1 according to their square root transformed mean. The least significant difference between lines is 1.8 at $P \leq 0.05$.

For DON, the effects of year, two-rowed versus six-rowed, and cultivar were significant $(P \leq 0.05)$. The average DON for the two-rowed cultivars was lower than the average for the six-rowed cultivars for both years (5.2 versus $8.8 \mathrm{ppm}$ in 1997 and 3.1 versus $3.9 \mathrm{ppm}$ in 1998). The average level of DON was higher in 1997 (7.1 ppm) than in 1998 (3.5 ppm), and was similar to the differences in FHB index between the 2 years. Cultivar comparisons using DON alone were not as useful as comparisons based on FHB index because only 2 years of data were available for DON, but they are listed for comparison with the FHB index in Table 1.

While the FHB index and DON concentration varied among years, the ranks of the barley lines generally were correlated $(P \leq 0.05)$ among years of testing using FHB index or DON and between FHB index and DON concentration (Table 2). The rankings of lines based on FHB index were correlated between each pair of years except for 1997 and 1995. Although DON content levels were measured only in 1997 and 1998, the rankings of lines based on DON were correlated between the 2 years of testing. The lines generally also were correlated with rankings based on FHB index, except that those based on DON in 1998 were not significantly correlated with rankings based on FHB index in 1996 and 1997. This may have resulted from poor separation of the lines based on DON in 1998 because the average DON level was relatively low (3.5 ppm).

Based on the average FHB index from 1995 and 1996, the original 158 barley lines were ranked from lowest to highest FHB index. During 1997 and 1998, two subsets of lines comprising the most resistant lines (18 lines with LFHB: 0.2 to 8.0 
in 1995 and 1.9 to 12.9 in 1996) and the most susceptible lines (12 lines with HFHB: 4.8 to 54.5 in 1995 and 31.4 to 70.1 in 1996) were selected for comparison with 27 RS lines that included 20 cultivars reported or thought to have resistance and 7 Canadian lines or cultivars. The effects of year, location, year-location interaction, two-rowed versus six-rowed type, and cultivar were significant $(P \leq$ 0.05 ) for both FHB index and DON. The 42 two-rowed cultivars had lower average FHB index values (14.0) than the 15 sixrowed cultivars (30.1). The LFHB lines generally had lower FHB index values and DON concentrations than the HFHB lines over both locations and both years (1997 and 1998) of testing (Table 3). The LFHB line 45 , which appeared to have some resistance during tests in 1995 and 1996, was fairly susceptible in all tests during 1997 and 1998. Some of the LFHB lines, such as Nepolegajuscij, Krasnojarskij, Nordic, Murasaki-mochi, Golozernyj 1, Maris Mink, Symko, Ussurijskij 8, Suvenir, ZAO-SU 3 and Akka W6039 and the Canadian cultivars or lines AC Sterling, T186-1, DB 202, DB 192, and Morrison were not significantly different $(P \leq 0.05)$ from the best resistance sources Zhedar1, Seijo II, and Chevron. Of these lines, Nepolegajuscij, Krasnojarskij, Nordic, Murakaki-mochi, Golozernyj 1, Maris Mink, Symko, Ussurijskij 8, Suvenir, AC Sterling, and Morrison also had consistently low DON content.

The average FHB index and DON concentration were higher for both years of testing in the inoculated nurseries than under natural infection at Carman. The rankings of the lines based on FHB index or DON generally were correlated $(P \leq$ 0.05 ) between different years and locations of testing (Table 4). Rankings based on DON levels from Carman in 1998 were less correlated with the other rankings, although most rank correlations still were significant. The DON levels were low for these lines grown at Carman in 1998 (0.1 to $2.2 \mathrm{ppm}$, average $=0.3 \mathrm{ppm}$ ), which resulted in poor separation of the lines.

\section{DISCUSSION}

There was a wide range of resistance to FHB among a group of 158 barley lines from diverse origins. Although the average level of FHB fluctuated among the four years of testing, the ranks of the lines were positively correlated between each pair of years tested except between 1995 and 1997. Lines with fewer visual symptoms of FHB may not have been distinguished in 1995 as well as they were in the other years due to the low average FHB index $(8.6 \%)$. Therefore, although the environment has a strong influence on FHB, the barley genotype also contributes significantly to the final level of FHB.

The 77 two-rowed cultivars, as a group, were significantly more FHB resistant than

Table 2. Spearman rank correlation coefficients among Fusarium head blight (FHB) index and deoxynivalenol (DON) concentration from 158 barley lines inoculated with F. graminearum in 1995, 1996, 1997, and 1998

\begin{tabular}{lcccccc}
\hline & \multicolumn{3}{c}{ FHB index } & & \multicolumn{2}{c}{ DON } \\
\cline { 2 - 4 } \cline { 6 - 7 } & $\mathbf{1 9 9 6}$ & $\mathbf{1 9 9 7}$ & $\mathbf{1 9 9 8}$ & & $\mathbf{1 9 9 7}$ & $\mathbf{1 9 9 8}$ \\
\hline FHB index 1995 & $0.16^{*}$ & 0.14 & $0.37^{* *}$ & & $0.25^{* *}$ & $0.29^{* *}$ \\
FHB index 1996 & $\ldots$ & $0.31^{* *}$ & $0.34^{* *}$ & & $0.33^{* *}$ & 0.15 \\
FHB index 1997 & $\ldots$ & $\ldots$ & $0.18^{*}$ & & $0.33^{* *}$ & 0.02 \\
FHB index 1998 & $\ldots$ & $\ldots$ & $\ldots$ & & $0.26^{* *}$ & $0.37^{* *}$ \\
DON 1997 & $\ldots$ & $\ldots$ & $\ldots$ & & $\ldots$ & $0.34^{* *}$ \\
\hline
\end{tabular}

a $*$ and $* *=$ Significant at $P \leq 0.05$ and 0.01 , respectively.

the 81 six-rowed cultivars (Table 1). Takeda and Heta (13) compared 1,244 tworowed cultivars and 3,637 six-rowed cultivars and also found that the two-rowed cultivars, as a group, were more FHB resistant than the six-rowed cultivars. The relationship between inflorescence type (two- or six-rowed) and FHB resistance in barley has not been explained fully, but Zhu et al. (17) found negative correlations between the number of seed per inflorescence and the severity of FHB in a cross between a pair of two-rowed cultivar. Most of the quantitative trait loci (QTL) for FHB resistance coincided with QTL for morphological traits, such as the type of inflorescence or plant height; therefore, Zhu et al. (17) concluded that plant architecture should be considered when breeding barley for FHB resistance. Steffenson et al. (12) compared two sets of paired isogenic barley lines with the members of each pair differing from each other for the two-rowed/six-rowed character and found that the two-rowed lines had slightly lower FHB and DON than the six-rowed lines in both isogenic pairs; however, these differences were not statistically significant.

Differences in the time of heading are always important when screening for FHB resistance. Our method of inoculation and harvesting heads for visual analysis in the inoculated nurseries was done for all lines over a 21-day period, starting at the heading date for each line; therefore, these differences between lines should be minimized. Because this 21-day window is different for lines with different heading dates, the naturally occurring rainfall and $F$. graminearum inoculum may not be the same for lines with different heading dates. Also, because DON analysis was conducted on grain from fully mature plants, the early heading lines would have been exposed to naturally occurring rainfall and $F$. graminearum inoculum over a longer period than lines that headed later.

One of the factors that could confound the visual FHB index ratings in barley is the presence of other fungi, particularly Cochliobolus sativus (Ito \& Kuribayashi) Drechs. ex Dastur (anamorph: Bipolaris sorokiniana (Sacc.)), the causal agent of barley spot blotch, which also can attack barley spikes and produce symptoms similar in appearance to those of FHB. If a spike is heavily infected with $C$. sativus, it may appear to have high levels of FHB, while in fact the level of seed colonization with $F$. graminearum is low (16). The DON measurement, therefore, is not only an important factor for barley marketability, but also provides an important indicator of the actual level of FHB and seed colonization by $F$. graminearum. Spot blotch also is a serious barley disease in the eastern Canadian prairies; therefore, cultivars suited to this region ideally would have a combination of resistance to $F$. graminearum, low DON accumulation, and resistance to $C$. sativus.

To determine the relative FHB resistance among a group of lines reliably has been difficult in barley because of the confounding effects of maturity, infection with other pathogens, variability from spike to spike, and other factors. It also is difficult to compare different sources of resistance if they are not evaluated under the same conditions. Based on the results from 1995 and 1996, the subset of 18 LFHB lines and 12 HFHB lines were compared along with 20 lines with reported FHB resistance and 7 Canadian cultivars or lines (RS) in both natural and artificially inoculated nurseries in 1997 and 1998. Generally, the LFHB and RS lines had lower FHB symptoms than the HFHB lines (Table 3), which were consistently susceptible, demonstrating that these two groups of lines (LFHB and HFHB) could be reliably distinguished. However, these differences were not absolute because the LFHB line 45 was relatively susceptible and the HFHB lines Varunda and Koru had FHB levels comparable to some of the resistant lines. LFHB lines Nepolegajuscij, Krasnojarskij, Nordic, Murakaki-mochi, Golozernyj 1, Maris Mink, Symko, Ussurijskij 8, Suvenir, ZAO-SU 3, and Akka W6039 had FHB index values that were not significantly different from the cultivars with the highest level of FHB resistance, Zhedar 1, Seijo II, and Chevron (Table 3). These lines also had consistently low DON levels, except for ZAO-SU 3 and Akka W6039. Additional lines from the original set of 158, such as Dziugiaj, PI25744 Franconian, and Nosovskij 6, also may have useful levels of FHB resistance. Some cultivars thought to have resistance (CIMMYT 6A, Fuji Nijo, and Zaoshu 3) were not very resistant under our testing conditions. This may reflect differences in 
Table 3. Fusarium head blight (FHB) index and deoxynivalenol (DON) for 18 low FHB index lines (LFHB), 12 high FHB index lines (HFHB), and 27 resistance sources (RS) under natural conditions at Carman MB and in inoculated, irrigated nurseries in 1997 and $1998^{\mathrm{a}}$

\begin{tabular}{|c|c|c|c|c|c|c|c|c|c|c|c|c|}
\hline \multirow[b]{3}{*}{ Cultivar } & \multirow[b]{3}{*}{ Source $^{\mathbf{b}}$} & \multirow[b]{3}{*}{ Row } & \multicolumn{4}{|c|}{ FHB index (\%) } & \multirow[b]{3}{*}{ Mean $^{c}$} & \multirow[b]{3}{*}{ Tr. mean ${ }^{d}$} & \multicolumn{4}{|c|}{ DON (ppm) } \\
\hline & & & \multicolumn{2}{|c|}{ Carman } & \multicolumn{2}{|c|}{ Nursery } & & & \multicolumn{2}{|c|}{ Carman } & \multicolumn{2}{|c|}{ Nursery } \\
\hline & & & 1997 & 1998 & 1997 & 1998 & & & 1997 & 1998 & 1997 & 1998 \\
\hline Zhedar 1 & $\mathrm{RS}^{\mathrm{e}}$ & 2 & 0.4 & 1.4 & 10.4 & 1.3 & 2.4 & 1.6 & 0.1 & 0.2 & 1.0 & 0.2 \\
\hline Seijo II & $\mathrm{RS}^{\mathrm{f}}$ & 2 & 0.2 & 1.7 & 10.6 & 3.9 & 3.0 & 1.8 & 1.3 & 0.1 & 2.2 & 0.3 \\
\hline Chevron & $\mathrm{RS}^{\mathrm{g}}$ & 6 & 0.4 & 1.8 & 11.7 & 4.4 & 3.5 & 1.9 & 0.1 & 0.3 & 1.4 & 0.3 \\
\hline Nepolegajuscij & LFHB & 2 & 0.6 & 1.3 & 10.2 & 5.7 & 3.5 & 1.9 & 0.2 & 0.2 & 2.6 & 0.2 \\
\hline Krasnojarskij 1 & LFHB & 2 & 1.3 & 1.3 & 10.7 & 5.5 & 3.9 & 2.0 & 0.5 & 0.2 & 4.4 & 1.3 \\
\hline Nordic & LFHB & 6 & 2.5 & 1.2 & 14.6 & 2.0 & 3.9 & 2.0 & 2.3 & 0.2 & 3.2 & 1.3 \\
\hline Harbin & $\mathrm{RS}^{\mathrm{f}}$ & 2 & 0.2 & 2.1 & 16.2 & 4.1 & 3.9 & 2.0 & 0.4 & 0.1 & 7.7 & 0.3 \\
\hline Murasaki-mochi & LFHB & 6 & 0.3 & 4.4 & 9.4 & 8.4 & 4.6 & 2.2 & $<0.1$ & 0.2 & 0.1 & 5.2 \\
\hline Golozernyj 1 & LFHB & 2 & 0.6 & 1.9 & 19.3 & 5.0 & 4.8 & 2.2 & $<0.1$ & 0.2 & 0.5 & 0.5 \\
\hline Svansota & $\mathrm{RS}^{\mathrm{f}, \mathrm{g}}$ & 2 & 0.8 & 2.3 & 15.8 & 6.1 & 4.9 & 2.2 & 0.1 & 0.2 & 2.0 & $\ldots$ \\
\hline Maris Mink & LFHB & 2 & 0.3 & 2.0 & 17.1 & 8.5 & 5.1 & 2.3 & 0.1 & 0.2 & 2.8 & $\ldots$ \\
\hline AC Sterling & $\mathrm{RS}^{\mathrm{h}}$ & 2 & 0.2 & 1.8 & 23.4 & 5.7 & 5.1 & 2.3 & 0.2 & 0.2 & 3.6 & 1.1 \\
\hline Frederickson & $\mathrm{RS}^{\mathrm{f}}$ & 2 & 0.7 & 5.8 & 18.4 & 2.9 & 5.3 & 2.3 & $<0.1$ & 0.1 & 2.6 & 0.3 \\
\hline Svanhals & $\mathrm{RS}^{\mathrm{fg}}$ & 2 & 0.1 & 4.8 & 23.1 & 4.2 & 5.5 & 2.3 & 0.1 & 0.2 & 10.2 & 2.2 \\
\hline T186-1 & $\mathrm{RS}^{\mathrm{h}}$ & 2 & 0.8 & 1.9 & 32.0 & 2.5 & 5.7 & 2.4 & 0.3 & 0.1 & 6.2 & 0.9 \\
\hline Symko & LFHB & 2 & 1.5 & 0.8 & 32.9 & 2.9 & 5.7 & 2.4 & 0.3 & 0.1 & 3.7 & 0.4 \\
\hline Niedzica 1 & $\mathrm{RS}^{\mathrm{f}}$ & 2 & 0.3 & 2.6 & 24.3 & 8.6 & 6.3 & 2.5 & 0.1 & 0.2 & 2.4 & $\ldots$ \\
\hline DB 202 & $\mathrm{RS}^{\mathrm{h}}$ & 2 & 1.1 & 5.7 & 23.3 & 4.2 & 6.6 & 2.6 & 0.1 & 0.1 & 6.1 & $\ldots$ \\
\hline Gobernadora & $\mathrm{RS}^{\mathrm{e}}$ & 2 & 4.6 & 3.0 & 23.9 & 5.0 & 7.6 & 2.8 & 1.6 & 0.2 & 10.2 & 3.3 \\
\hline Ussurijskij 8 & LFHB & 2 & 0.2 & 2.2 & 31.6 & 12.9 & 7.8 & 2.8 & $<0.1$ & 0.2 & 1.1 & 0.3 \\
\hline Suvenir & LFHB & 2 & 4.3 & 2.3 & 10.9 & 19.3 & 8.0 & 2.8 & 0.3 & 0.2 & 2.3 & \\
\hline CI 8826 & $\mathrm{RS}^{\mathrm{f}}$ & 2 & 5.9 & 6.2 & 15.7 & 6.0 & 8.0 & 2.8 & 0.5 & 0.2 & 2.6 & 0.8 \\
\hline DB 192 & $\mathrm{RS}^{\mathrm{h}}$ & 2 & 1.0 & 2.6 & 44.1 & 5.9 & 8.5 & 2.9 & 0.2 & 0.1 & 9.0 & $\ldots$ \\
\hline Morrison & $\mathrm{RS}^{\mathrm{h}}$ & 2 & 0.4 & 9.6 & 31.9 & 7.8 & 9.3 & 3.0 & 2.8 & 0.1 & 4.4 & 1.7 \\
\hline Kyoto Nakate & $\mathrm{RS}^{\mathrm{f}}$ & 2 & 8.3 & 6.5 & 19.7 & 5.4 & 9.3 & 3.1 & 0.1 & 0.1 & 2.9 & 0.2 \\
\hline ZAO-SU 3 & LFHB & 2 & 2.6 & 6.5 & 24.9 & 12.2 & 10.0 & 3.2 & 0.5 & 0.2 & 2.3 & 7.5 \\
\hline Akka W6039 & LFHB & 2 & 0.8 & 1.8 & 39.4 & 22.7 & 11.0 & 3.3 & 0.4 & 0.2 & 3.4 & 5.2 \\
\hline Tristan & LFHB & 2 & 26.9 & 0.9 & 32.8 & 3.7 & 11.9 & 3.4 & 0.4 & 0.1 & 1.1 & 1.8 \\
\hline Horni Peseky 2 & $\mathrm{RS}^{\mathrm{fg}}$ & 2 & 4.3 & 3.2 & 59.4 & 5.8 & 12.2 & 3.5 & 0.9 & 0.1 & 6.3 & 0.7 \\
\hline Wing & LFHB & 2 & 5.3 & 2.4 & 16.7 & 39.5 & 12.6 & 3.6 & 0.4 & 0.2 & 1.2 & 0.1 \\
\hline Manker & LFHB & 2 & 9.8 & 3.0 & 18.8 & 25.4 & 12.7 & 3.6 & 0.9 & 0.2 & 6.5 & 2.7 \\
\hline Hazen & LFHB & 6 & 7.6 & 3.6 & 49.8 & 7.5 & 13.0 & 3.6 & 0.6 & 0.3 & 5.2 & 1.3 \\
\hline Varunda & HFHB & 2 & 0.6 & 7.2 & 29.2 & 32.1 & 13.2 & 3.6 & 0.2 & 0.2 & 3.2 & 24.2 \\
\hline Hassan & LFHB & 2 & 3.5 & 3.6 & 31.6 & 32.1 & 14.2 & 3.8 & 0.6 & 0.2 & 3.0 & 0.3 \\
\hline Clho 1554 Hanna & LFHB & 2 & 11.4 & 5.7 & 54.4 & 4.0 & 14.3 & 3.8 & 0.4 & 0.1 & 5.7 & 0.6 \\
\hline Koru & HFHB & 2 & 7.4 & 6.0 & 37.9 & 15.6 & 14.6 & 3.8 & $<0.1$ & 0.2 & 2.5 & 13.6 \\
\hline Maja & $\mathrm{RS}^{\mathrm{f}}$ & 2 & 6.9 & 17.4 & 27.0 & 14.6 & 15.6 & 4.0 & 1.0 & 0.1 & 4.9 & $\ldots$ \\
\hline AB 159-2 & $\mathrm{RS}^{\mathrm{h}}$ & 2 & 5.9 & 9.0 & 45.4 & 18.3 & 16.9 & 4.1 & 0.1 & 0.1 & 3.3 & 1.5 \\
\hline Asahi 5 & $\mathrm{RS}^{\mathrm{f}}$ & 2 & 1.6 & 16.2 & 40.0 & 23.5 & 16.9 & 4.1 & 2.8 & 1.1 & 22.5 & 10.6 \\
\hline Fuji Nijo & $\mathrm{RS}^{\mathrm{f}, \mathrm{g}}$ & 2 & 27.6 & 6.9 & 32.8 & 9.1 & 17.3 & 4.2 & 1.9 & 0.1 & 6.5 & 2.6 \\
\hline Primus & $\mathrm{RS}^{\mathrm{f}}$ & 2 & 1.2 & 16.7 & 44.7 & 27.5 & 18.3 & 4.3 & 0.1 & 0.2 & 1.1 & 0.1 \\
\hline AC Stephen & $\mathrm{RS}^{\mathrm{h}}$ & 2 & 15.3 & 6.5 & 50.5 & 13.2 & 18.5 & 4.3 & 1.3 & 0.1 & 11.2 & 6.5 \\
\hline Zaoshu 3 & $\mathrm{RS}^{\mathrm{i}}$ & 2 & 3.2 & 33.9 & 26.9 & 22.7 & 19.3 & 4.4 & 1.9 & 0.2 & 12.8 & 7.5 \\
\hline Beecher & HFHB & 6 & 10.6 & 11.7 & 32.7 & 35.4 & 21.0 & 4.6 & 3.3 & 0.4 & 15.0 & 1.4 \\
\hline Paavo & HFHB & 6 & 3.6 & 31.4 & 23.3 & 36.7 & 21.1 & 4.6 & 1.0 & 0.2 & 4.9 & 1.1 \\
\hline Zita & HFHB & 2 & 5.0 & 37.5 & 36.4 & 18.7 & 21.9 & 4.7 & $<0.1$ & 0.2 & 4.4 & 0.4 \\
\hline Korsbyg & $\mathrm{RS}^{\mathrm{j}}$ & 6 & 37.2 & 27.1 & 16.9 & 14.6 & 23.1 & 4.8 & 1.8 & 0.2 & 5.5 & 0.8 \\
\hline Hх690 & HFHB & 6 & 42.8 & 3.3 & 50.9 & 21.2 & 25.2 & 5.0 & 4.5 & 0.2 & 19.6 & 5.0 \\
\hline Dissa & HFHB & 6 & 10.5 & 20.8 & 59.2 & 26.2 & 26.6 & 5.2 & 1.8 & 0.3 & 14.4 & $\ldots$ \\
\hline B 3152A & $\mathrm{RS}^{\mathrm{j}}$ & 6 & 12.8 & 12.1 & 91.0 & 29.9 & 30.4 & 5.5 & 3.4 & 0.1 & 39.7 & 2.3 \\
\hline PI48641 Fidel & HFHB & 2 & 53.3 & 21.6 & 61.4 & 13.9 & 34.6 & 5.9 & 3.3 & 0.4 & 58.7 & 0.1 \\
\hline Cimmyt 6A & $\mathrm{RS}^{\mathrm{j}}$ & 6 & 75.3 & 11.4 & 83.8 & 20.8 & 41.5 & 6.4 & 2.9 & 0.2 & 82.3 & 9.0 \\
\hline Du Li-huang & HFHB & 6 & 38.9 & 53.6 & 41.3 & 33.9 & 41.6 & 6.5 & 1.6 & 0.2 & 4.7 & 1.1 \\
\hline Hankkijan Potra & HFHB & 6 & 54.2 & 39.1 & 36.3 & 57.4 & 46.3 & 6.8 & 5.9 & 0.8 & 12.6 & 16.1 \\
\hline Suvi & HFHB & 6 & 65.8 & 53.0 & 16.7 & 61.4 & 46.6 & 6.8 & 3.6 & 0.5 & 12.1 & 15.7 \\
\hline 45 & LFHB & 2 & 65.7 & 27.2 & 43.4 & 57.0 & 47.1 & 6.9 & 2.9 & 2.2 & 11.0 & 14.0 \\
\hline Etu & HFHB & 6 & 69.3 & 75.8 & 61.1 & 65.1 & 67.7 & 8.2 & 1.3 & 0.5 & 8.9 & 6.9 \\
\hline Averages & $\ldots$ & $\ldots$ & 12.7 & 11.5 & 31.9 & 17.0 & 15.8 & 3.7 & 1.1 & 0.3 & 8.6 & 3.3 \\
\hline
\end{tabular}

a ... Indicates missing data or not applicable.

${ }^{\mathrm{b}}$ LFHB = lines with low FHB index values in 1995 (0.2 to 8.0) and 1996 (1.9 to 12.9), HFHB = lines with high FHB index values in 1995 (4.8 to 54.5$)$ and 1996 (31.4 to 70.1), RS = reported sources of FHB resistance $(2,9,16)$ and Canadian cultivars or lines.

${ }^{c}$ Means were obtained by squaring the transformed mean.

d Transformed mean: the mean of the FHB index transformed by square root. The least significant difference $(P \leq 0.05)$ between the transformed mean for any two lines is 1.7 .

${ }^{\mathrm{e}}$ Resistance source identified by Gilchrist et al. (2).

${ }^{\mathrm{f}}$ Resistance source identified by Takeda and Heta (13).

g Resistance source identified by Prom et al. (9).

${ }^{\mathrm{h}}$ Canadian cultivar or breeding line.

${ }^{\mathrm{i}}$ Line provided by Ruth Dill-Macky, Department of Plant Pathology, University of Minnesota.

j Lines provided by George Fedak, Agriculture and Agri-Food Canada. 
F. graminearum isolates used as inoculum, environmental conditions, or inoculation methods used between our study and others.

Of the 23 FHB-resistant two-rowed barley lines identified by Takeda and Heta (13), 13 were tested for FHB resistance (Table 3). These lines were Seijo II, Harbin, Svansota, Frederickson, Svanhals, Niedzica 1, CI 8826, Kyoto Nakate, Horni Peseky 2, Maja, Asahi 5, Fuji Nijo, and Primus. Although Takeda and Heta (13) listed these lines among the resistant lines from the 5,000 they tested, they did not indicate the relative levels of FHB resistance among these lines. Seijo II, Svansota, Frederickson, and Svanhals were among the most resistant of the lines tested (Table 3), but other lines identified by Takeda and Heta (13), such as Maja, Asahi 5, Fuji Nijo, and Primus, were not highly resistant in our tests.

Malting barley cultivars grown in western Canada have been predominantly tworowed types dominated by the popular cv. Harrington (7). There appears to be a more diversified pool of two-rowed FHB-resistant cultivars than for six-rowed cultivars. The FHB indices for the Canadian tworowed cultivars Symko, AC Sterling, T1861, DB 202, DB 192, and Morrison were not different $(P \leq 0.05)$ from Zhedar 1 , Seijo II, and Chevron, which were reported to be resistant $(2,9,13$; Table 3$)$. Resistance in these lines may have resulted from selection for disease resistance in eastern Canada where these cultivars and lines were developed. Tests of additional Canadian barley cultivars conducted in the same FHB nurseries as those used in this study demonstrated that western Canadian two-rowed cultivars AC Oxbow and AC Metcalfe had similar levels of resistance to AC Sterling (A. Tekauz, unpublished data). Some of the Canadian two-rowed cultivars had resistance levels similar to sources reported to have resistance; therefore, it may be difficult to substantially improve the level of FHB resistance in Canadian two-rowed cultivars through plant breeding. However, if different sources of resistance acted in an additive or complementary fashion, when these Canadian cultivars were crossed with effective two-rowed sources of resistance like Zhedar 1 or Seijo II, some transgres- sive segregation for resistance may be found in the progeny. Further research is needed to determine the genetic basis for FHB resistance in barley.

Feed barley cultivars in western Canada include two-rowed types, but six-rowed types are predominant in the eastern prairie region (7). Most of the six-rowed cultivars grown in the eastern prairies of Canada, such as Excel and Robust, are more susceptible to FHB than two-rowed cultivars grown in the same area (16). Barley breeding programs in the United States, which are focussed primarily on six-rowed barley, have extensively used Chevron as a source of FHB resistance (10). Chevron was among the most resistant lines in our tests (Table 2). The six-rowed cultivars Murasaki-mochi and Nordic appeared to have good levels of resistance (Tables 1 and 3) and could be used in addition to Chevron as sources of resistance within the six-rowed pool of germ plasm. Crosses between adapted high-quality six-rowed cultivars and FHB-resistant two-rowed cultivars also have been attempted both in Canada and in the United States.

The lines in this study were characterized only for their reaction to FHB and DON accumulation. Although many of these lines may have useful levels of FHB resistance, their suitability as parents in breeding programs could depend on a number of other factors, such as plant height, head architecture, maturity, yield, and quality. It is encouraging to note that some Canadian two-rowed cultivars appear to have useful levels of FHB resistance and already are well adapted agronomically to the areas of Canada and the northern United States where FHB is a major problem.

\section{ACKNOWLEDGMENTS}

We thank M. Stulzer, E. Mueller, I. Mohamednur, R. Kaethler, J. Noll, and U. Kromer for technical assistance; M. Savard and his staff for analysis of DON; G. Fedak and R. Dill-Macky for providing seed for many of the RS lines; and J. Menzies, S. Woods, T. Fetch, and J. Gold Steinberg for advice on the manuscript.

\section{LITERATURE CITED}

1. Fernandez, M. R., Pearse, P. G., Holzgang, G., and Hughes, G. R. 2001. Fusarium head blight of barley in Saskatchewan in 2000. Can. Plant Dis. Surv. 81:61-62.

2. Gilchrist, L., Rajaram, S., Mujeeb-Kazi, A., van Ginkel, M., Vivar, H., and Pfeiffer, W. 1997. Fusarium scab screening program at CIMMYT. Pages 7-12 in: Fusarium Head Blight: Global Status and Future Prospects. $\mathrm{H}$. J. Dubin, L. Gilchrist, J. Reeves, and A. McNab, eds. CIMMYT, Mexico D.F.

3. McCallum, B., Tekauz, A., Gilbert, J., Gold, J., Idris, M., Mueller, E., Kaethler, R., Stulzer M., and Kromer, U. 2000. Fusarium head blight of barley in Manitoba in 1999. Can. Plant Dis. Surv. 80:36.

4. McCallum, B., Tekauz, A., Gilbert, J., Mueller, E., Kaethler, R., Stulzer, M., and Kromer, U. 1998. Fusarium head blight of barley in Manitoba in 1997. Can. Plant Dis. Surv. 78:74

5. McCallum, B., Tekauz, A., Gilbert, J., Mueller, E., Kaethler, R., Stulzer, M., and Kromer, U. 1999. Fusarium head blight of barley in Manitoba in 1998. Can. Plant Dis. Surv. 79:7576.

6. McMullen, M., Enz, P., Lukach, J., and Stover, R. 1997. Environmental conditions associated with Fusarium head blight epidemics of wheat and barley in the Northern Great Plains, North America. Cereal Dis. Commun. 25:777-778.

7. Metcalfe, D. R. 1995. Barley. Pages 82-97 in: Harvest of Gold-The History of Field Crop Breeding in Canada. A. E. Slinkard and D. R. Knott., eds. University Extension Press, University of Saskatchewan, Saskatoon, SK, Canada.

8. Paulitz, T. C. 1999. Fusarium head blight: a reemerging disease. Phytoprotection 80:127-133.

9. Prom, L. K., Steffenson, B. J., Salas, B., Fetch, Jr., T. G., and Casper, H. H. 1996. Evaluation of selected barley accessions for resistance to Fusarium head blight and deoxynivaleno concentration. Pages 764-766 in: Proc. 5th Int. Oat Conf. and 7th Int. Barley Genet. Symp. G. Scoles and B. Rossnagel, eds. University Extension Press, University of Saskatchewan, SK, Canada.

10. Rudd, J. C., Horsley, R. D., McKendry, A. L., and Elias, E. M. 2001. Host plant resistance genes for Fusarium head blight: sources, mechanisms, and utility in conventional breeding systems. Crop Sci. 41:620-627.

11. Sinha, R. C., Savard, M. E., and Lau, R. 1995. Production of monoclonal antibodies for the specific detection of deoxynivalenol and 15acetyldeoxynivalenol by ELISA. J. Agric. Food Chem. 43:1740-1744.

12. Steffenson, B. J., Prom, L. K., Salas, B., Fetch, T. G., Wesenberg, D. G., and Bockelman, H. E. 1996. Severity of Fusarium head blight and concentrations of deoxynivalenol in nearisogenic lines of barley differing for several agronomic characters. Pages 774-776 in: Proc. 5th Int. Oat Conf. and 7th Int. Barley Genet. Symp. G. Scoles and B. Rossnagel, eds University Extension Press, University of Saskatchewan, SK, Canada.

13. Takeda, K., and Heta, H. 1989. Establishing the testing method and a search for resistant varieties to Fusarium head blight in barley. Jap. J. Breed. 39:203-216.

14. Tekauz, A., Gilbert, J., Gold, J., Mueller, E.,

Table 4. Spearman rank correlation coefficients among Fusarium head blight (FHB) index (\%) and deoxynivalenol (DON, ppm) content from 57 barley lines under natural conditions at Carman, MB and in nurseries inoculated with Fusarium graminearum in 1997 and $1998^{\mathrm{a}}$

\begin{tabular}{|c|c|c|c|c|c|c|c|}
\hline & \multicolumn{3}{|c|}{ FHB } & \multicolumn{4}{|c|}{ DON } \\
\hline & Carman 1998 & Nursery 1997 & Nursery 1998 & Carman 1997 & Carman 1998 & Nursery 1997 & Nursery 1998 \\
\hline Carman FHB index 1997 & $0.60 * *$ & $0.54 * *$ & $0.52 * *$ & $0.65^{* *}$ & 0.22 & $0.54 * *$ & $0.37 * *$ \\
\hline Carman FHB index 1998 & $\ldots$ & $0.47 * *$ & $0.70 * *$ & $0.45 * *$ & $0.30^{*}$ & $0.52 * *$ & $0.38^{* *}$ \\
\hline Nursery FHB index 1997 & $\ldots$ & $\ldots$ & $0.38 * *$ & $0.37 * *$ & 0.01 & $0.56^{* *}$ & $0.30^{*}$ \\
\hline Nursery FHB index 1998 & $\ldots$ & $\ldots$ & $\ldots$ & $0.45 * *$ & $0.53 * *$ & $0.35 * *$ & $0.44 * *$ \\
\hline Carman DON 1997 & $\ldots$ & $\ldots$ & $\ldots$ & $\ldots$ & $0.27 *$ & $0.72 * *$ & $0.45 * *$ \\
\hline Carman DON 1998 & $\ldots$ & $\ldots$ & $\ldots$ & $\ldots$ & $\ldots$ & 0.16 & $0.28 *$ \\
\hline Nursery DON 1997 & $\ldots$ & $\ldots$ & $\ldots$ & $\ldots$ & $\ldots$ & $\ldots$ & $0.46 * *$ \\
\hline
\end{tabular}

a $*$ and $* *$ Significant at $P \leq 0.05$ and 0.01 , respectively. 
Idris, M., Stulzer, M., Beyene, M., and Nedohin, E. 2001. Fusarium head blight of barley in Manitoba and south-east Saskatchewan in 2000. Can. Plant Dis. Surv. 81:65.

15. Tekauz, A., Gilbert, J., Mueller, E., Stulzer, M., Kaethler, R., and Nedohin, E. 2002. Fusarium head blight of barley in Manitoba in
2001. Can. Plant Dis. Surv. 82:57-58.

16. Tekauz, A., McCallum, B., and Gilbert, J. 2000. Review: Fusarium head blight of barley in western Canada. Can. J. Plant Pathol. 22:916.

17. Zhu, H., Gilchrist, L., Hayes, P., Kleinhofs, A., Kudrna, D., Liu, Z., Prom, L., Steffenson, B.,
Trojinda, T., and Vivar, H. 1999. Does function follow form? Principal QTLs for Fusarium head blight (FHB) resistance are coincident with QTLs for inflorescence traits and plant height in a doubled haploid population of barley. Theor. Appl. Genet. 99:1221 1232 . 